\title{
Media Sosial sebagai Gerakan Sosial Digital: Studi Kasus Akun Instagram @Aliskamugemash dalam Menyuarakan Kejahatan Seksual LWD terhadap Perempuan
}

\author{
Renata Maharani ${ }^{1}$ \\ Ilmu Pemerintahan, Universitas Sultan Ageng Tirtayasa \\ 6670180028@untirta.ac.id \\ Nadika M. Ardiansyah ${ }^{2}$ \\ Ilmu Pemerintahan, Universitas Sultan Ageng Tirtayasa \\ 6670180067@untirta.ac.id \\ Rista Bella Annisa ${ }^{3}$ \\ Ilmu Pemerintahan, Universitas Sultan Ageng Tirtayasa \\ 6670180113@untirta.ac.id \\ Zidan Hizbullah ${ }^{4}$ \\ Ilmu Pemerintahan, Universitas Sultan Ageng Tirtayasa \\ 6670180116@untirta.ac.id
}

\section{E-ISSN 2721-0642}

Article Info

Recieved:

June 292021

Revised:

July 282021

Accepted:

July 312021

Doi Number

https://doi.org/10.37950/ijd.v3i2.96

\begin{abstract}
In this era of globalization, technology is increasingly being used in all areas of life which has a major impact on social interactions among people. This is marked by the existence of social changes in communication carried out by the community both directly and in cyberspace through digital platforms such as social media applications. Over time, the use of digital platforms is not only used as a means of communication, but is also used in carrying out a digital-based social movement called a digital movement. Like the presence of the Instagram account @aliskamugemash as the embodiment of a digital-based social movement in exploring and preventing the emergence of fraud victims from online dating applications. The research we conducted used a descriptive qualitative approach. With the aim of research to examine and in-depth analysis related to social movements and collective behavior with the @aliskamugemash Instagram account case study. The results found various interactions or movements of Instagram users who participated in voicing and disseminating information to all women to be more careful, as well as to avoid similar incidents from happening to other women.
\end{abstract}

Keywords: digital social movements, sexual crimes, digital platforms, fraud. 


\section{Abstrak}

Pada era globalisasi ini teknologi semakin gencar digunakan dalam segala bidang kehidupan yang kemudian pun berdampak besar pula pada interaksi sosial di antara masyarakat. Hal ini ditandai dengan adanya perubahan sosial dalam berkomunikasi yang dilakukan oleh masyarakat baik dilakukan secara langsung maupun dengan dunia maya melalui platform digital seperti aplikasi sosial media. Seiring berkembangnya waktu, penggunaan platform digital tidak semata-mata hanya digunakan sebagai alat berkomunikasi saja, namun dimanfaatkan pula dalam melakukan sebuah pergerakan sosial berbasis digital yang disebut digital movement. Seperti hadirnya akun Instagram @aliskamugemash sebagai perwujudan sebuah gerakan sosial berbasis digital dalam mengupas dan mencegah munculnya korban penipuan dari aplikasi kencan online. Penelitian yang kami lakukan menggunakan pendekatan kualitatif deskriptif. Dengan tujuan penelitian untuk menelaah dan analisis mendalam terkait gerakan sosial dan perilaku kolektif yang dengan studi kasus akun Instagram @aliskamugemash. Hasilnya ditemukan beragam interaksi ataupun gerakan para pengguna instagram yang ikutserta menyuarakan dan menyebarluaskan informasi kepada seluruh perempuan untuk lebih berhati-hati, juga menghindari kejadian serupa berulang pada perempuan lainnya.

Kata kunci: gerakan sosial digital, kejahatan seksual, platform digital, penipuan.

\section{Pendahuluan}

Kehidupan sosial terdiri atas individu-individu yang memiliki perbedaan, mulai dari beragamnya budaya, pemikiran, tujuan hidup, bahkan latar belakang orientasi seksual yang berbeda antara satu dengan lainnya, kerapkali muncul di sekitar kita. Akan tetapi dalam mewujudkan keterbutuhan dan tujuan hidup individu satu dan yang lainnya perlu melakukan sebuah interaksi sebagai faktor utama yang berdampak besar dalam kehidupan sosial. Kemajuan teknologi era digitalisasi tentu sangat berdampak besar pada Interaksi sosial, Douglas Oliver (dalam Slamet, 2010) menyatakan bahwa interaksi dapat terjadi penyesuai pola tingkah laku antar berbagai individu, hingga sekelompok masyarakat tidak mampu mempertahankan dirinya tanpa adanya penyesuaian. Setiap anggota pada kelompok sosial berinteraksi melalui komunikasi, baik dunia nyata maupun dunia maya melalui platfom digital semisal Instagram, facebook, twitter, dan lainnya.

Semua platform digital tersebut menjadikan setiap individu sebagai pengguna yang turut memiliki konten sosial, sehingga suatu peristiwa yang terjadi di dunia nyata juga akan diperbincangan dan mempengaruhi media sosial. Begitupun sebaliknya, media sosial turut mempengaruhi kehidupan nyata. Berorientasi pada kepentingannya individu dalam media sosial juga turut menyuarakan baik pihak yang bersangkutan langsung sebagai pihak terdampak maupun bagian kelompok lain, sebab adanya altrurisme serta nilai ethics yang membuatnya turut ikut serta pada pergerakan sosial dalam platform digital (Digital Movement). Apalagi dengan kehadiran internet di lingkungan masyarakat yang memiliki jangkauan yang lebih besar daripada pergerakan sosial yang dilakukan secara konvensional pun nyatanya memberikan efek yang lebih besar pula, sehingga memberikan kesempatan yang lebih besar dari para penggerak aksi sosial ini dalam menyuarakan aspirasinya, pendapatnya serta memutus pembatas yang kerapkali menutup suara mereka. 
Pada era digital saat ini, manusia dimudahkan untuk memenuhi kebutuhan hidupnya, dengan orientasi ini sejumlah aplikasi yang beredar di masyarakat pun disesuaikan pula dengan kebutuhan, semisal adanya aplikasi jual-beli atau yang dikenal dengan e-Commerse, aplikasi belajar secara online, hingga dalam urusan kencan online yang salah satunya yaitu aplikasi Tinder. Aplikasi yang hadir bagi publik sejak tahun 2012 ini bertujuan untuk mempermudah interaksi individu satu dengan lainnya hanya dengan menggeser layar telepon genggam ke kanan dan ke kiri yang dapat diakses kapan saja dan dimana saja (Anggraeni, 2020). Semenarik dan sesempurnanya sebuah karya jika tidak digunakan secara bijak oleh individu yang tepat, pasti akan menimbulkan kerugian seperti beberapa kasus menimpa para pengguna aplikasi kencan online tersebut, seperti kasus pembunuhan dan penipuan yang dilakukan oleh seorang perempuan di India bernama Priya Seth. Hingga pemberitaan Indonesia beberapa bulan yang lalu tentang penemuan mayat mutilasi yang ditemukan di Apartemen Kalibata City, Jakarta, yang mana setelah dilakukan penyelidikan kasus ini berawal dari perkenalan antara korban dan pelaku melalui aplikasi Tinder (Nurfajiani, 2020).

Pada tulisan ini peneliti akan mengkaji sebuah kasus yang menyeret ratusan korban perempuan. Tersangkanya adalah seorang pria bernama Leonardus Wahyu Dewala atau LWD, melalui dating apps tersangka LWD melakukan pelecehan seksual dan juga penipuan. Beberapa dating apps yang digunakan LWD pada saat menjalankan aksinya yaitu aplikasi Tinder, aplikasi Tantan, dan aplikasi Badoo. Persoalan ini menjadi viral sejak para korban berani untuk speak up melalui beberapa platfom digital dari twitter hingga akun instagram @aliskamugemash yang menguak modus-modus predator seksual serta rentetan fakta-fakta yang dialami para korban, melalui bukti tangkapan layar obrolan para korban dengan tersangka.

Kejahatan yang dilakukan LWD ini mengundang kekecewaan banyak korban, hingga pada akhirnya unggahan sebuah akun @GRESAIDS yang memperingatkan kepada seluruh perempuan di daerah Jawa Tengah untuk berhati-hati jika bertemu dengan pengguna akun aplikasi kencan dengan nama "Leonardus Wahyu Dewala" pada 15 Januari 2021 lalu. Pasalnya Grace selaku pemilik akun menerangkan jika Leonardus adalah predator seksual juga tidak segan menipu korban demi keuntungannya (Ariana, 2021).

Hingga ini menjadi sebuah gagasan utama terciptanya akun Instagram dengan username@aliskamugemash sebagai bentuk pergerakan sosial secara digital dalam menupas serta mencegah munculnya korban-korban baru yang disebabkan oleh Leonardus. Akun yang terbentuk sejak Maret tahun 2020 ini berisikan dengan beragam tangkapan layar yang berisikan aduan-aduan dari para korban penipuan dan pelecehan yang dilakukan oleh Dewala. Selain itu akun dengan pengikut hingga 36 ribu ini pun juga mempublikasikan terkait isu-isu yang sama dengan tindakan yang dilakukan LWD yaitu seperti peringatan dengan adanya predator seksual dan sebagainya.

Melalui pengakuan para korban dapat diketahui bahwa peristiwa ini telah terjadi sejak tahun 2013 silam, dan telah menjerat ratusan korban (perempuan dibawah umur, hingga usia dewasa). Adapun peta pesebaran para korban kejahatan seksual LWD yaitu wilayah Semarang, Magelang, Solo, hingga Yogyakarta. Modus yang LWD gunakan dalam menjerat target korbannya yang bermayoritas perempuan melalui pengakuan para korban, LWD mengaku bahwa dia lulusan S2 salah satu jurusan di Universitas Gadjah Mada, lalu melanjutkan studi S3 pada Universitas ternama di Swiss. Tidak berhenti sampai di sana LWD juga acapkali mengakui dirinya menjalin kedekatan 
dengan Para tokoh penting seperti Bu Sri Mulyani (Menteri Keuangan Negara Indonesia), Bapak Tirto Karnavian (Menteri Dalam Negeri Indoenesia), hingga pengakuan bahwa Omnya seorang Bupati. Untuk menambah rasa kagum perempuan yang didekatinya LWD pernah mengakui bahwa dirinya terbiasa memakai Ajudan dalam beraktivitas dengan alasan begitu padat keseharian yang dilaluinya.

Melalui pengakuan para korban LWD menarik perhatian perempuan incarannya di dating apps. Dengan melontarkan pujian pada fisik korban, salah satu yang paling berkesan dan menjadi identitas dari praktik kejahatan LWD yaitu "alis kamu so gemas deh". Salah satu imbas atas kejahatan yang dilakukan LWD, yaitu banyak korban mengatakan kalau dirinya menderita penyakit kelamin hingga hamil. Pria ini juga tidak ragu untuk menggunakan kekerasan serta melakukan perekaman untuk mengancam para korban. Ada juga korban yang dipaksa melakukan aborsi, dan tidak sedikit pula korban mengalami kerugian materi karena dimintai sejumlah uang serta barang berharganya dengan ancaman akan menyebarluaskan video panas milik korban. Mengingat banyaknya korban dan besarnya meruginya kerugian korban, hingga sejumlah pergerakaan sosial basis digital ditunjukan untuk mengantisipasi kejahatan serupa. Maka penelitian ini begitu menarik untuk dibahas fokus pada penelitian ini yakni, "Bagaimanakah pergerakan dan perilaku digital masyarakat yang menyuarakan ketidakadilan terhadap sejumlah perempuan korban Leonardus Wahyu Dewala dalam akun@aliskamugemash?"

Pertanyaan tersebut menjadi penting untuk diangkat karena melihat fenomena yang ada kini di tengah kemajuan teknologi abad ini, masyarakat memiliki alternatif media untuk berkomunikasi yakni melalui media sosial yang mana wadah komunikasi ini dimanfaakan masyarakat sebagai wadah untuk menyampaikan opininya. Selain itu kejahatan di era modernisasi seperti saat ini tidak lagi memandang batas jarak dari segi wilayah, melalui platform media sosial serupa aplikasi kencan online, kejahatan bisa menjebak siapa saja semisal dari perkenalan dan modus-modus baru kejahatan seksual yang digencarkan LWD demi keuntungan dan kepuasan nafsu LWD belaka. Ini menjadi urgensi besar mengapa isu gerakan digital ini menarik untuk dipelajari mengingat perempuan memiliki hak untuk mendapatkan rasa aman dan terhindar dari kejahatan seksual, yang diatur dalam Kitab Undang-Undang Hukum Pidana (KUHP) Pasal 281 ayat 1 perihal tindak pidana melanggar kesusilaan dan pencabulan terhadap perempuan.

\section{Kerangka Teori}

Perilaku pergerakan yang disuarakan melalui akun Instagram @aliskamugemash ini merupakan bentuk dari connective action, karena individu bergerak berdasarkan konektivitasnya di dalam media digital. Beberapa individu yang merasa simpati dan yang menjadi korban dapat dengan bebas menyuarakan tanpa adanya ikatan dari organisasi ataupun kelompok tertentu karena dalam connective action ini yang jadi sorotan adalah rasa puas dari pengekspresian melalui jejaring sosial. Media sosial menjadi wadah yang bersifat fleksibel, cair, dan tidak mengikat secara individu membuat banyak orang lebih berani dan nyaman dalam menyampaikan suaranya tetapi walaupun demikian mereka tetap akan terkoneksi dengan yang lainnya karena rasa kepedulian bersama akan isu tertentu (Segerberg, 2013).

Dari fenomena tersebut, peneliti melihat jika tanpa kita sadari kehadiran berbagai platform media sosial Instagram pun secara tidak langsung berupaya dalam membentuk publik untuk mengakses akun tersebut menjadi turut merasakan, memiliki rasa 
persamaan dalam berjuang dan disatukan dalam sebuah platform berbasis digital. Ini membuktikan bahwa di era informasi saat ini sudah lahir suatu konsep baru yakni digital citizenship yakni suatu masyarakat yang menggunakan internet sebagai kebiasaan dalam kesehariannya dan mempunyai kemampuan untuk berpartisipasi dalam lingkup masyarakat secara daring (Mossberger et al., 2008).

Oleh sebab itu, di era informasi saat ini masyarakat digital memanfaatkan platform digitalnya dalam menyuarakan suaranya agar terdengar dengan melakukan suatu gerakan sosial yang memanfaaatkan platform digital dalam mengorganisasi keluhan yang ada secara kolektif yang mana disebut sebagai digital movement (Melgaço \& Monaghan, 2018). Margolis dan Moreno-Riano (2009, dalam Koc-Michalska et al., 2016) mengatakan bahwa masyarakat yang sudah akrab dengan platform digital cenderung berpartisipasi aktif dalam kegiatan aktivisme kelompok yang berbagai macamnya.

Dalam situasi ini, keresahan atas kasus penipuan Leonardus Wahyu Dewala disuarakan melalui media sosial dimana media sosial oleh Bonilla dan Rosa (2015, dalam Melgaço \& Monaghan, 2018) memiliki fungsi sebagai suatu ruang dan alat perlawanan yang dapat membuka ruang kontestasi juga dapat memberikan versi lain dari narasi yang diutarakan dalam media mainstream. Berangkat dari hal tersebut, penelitian ini akan melakukan telaah terkait gerakan sosial dan perilaku kolektif yang ditunjukkan melalui akun media sosial Instagram @aliskamugemash.

Terlebih, media sosial oleh Beck dan Beck-Gernsheim (2002, dalam Trottier \& Fuchs, 2015) erat kaitannya dengan framing pengguna dalam hal ini individu sebagai unit dari jaringan sehingga aktivitas pengguna dalam media sosial mencerminkan masyarakat secara individual yang mana ini merupakan cerminan dari Democracy 2.0 sebagaimana diutarakan oleh Trottier dan Fuchs (2015) yakni demokrasi yang hadir pada tubuh Web 2.0 dengan fitur komentar, like, dan berbagi dalam plaftorm media sosial dimana prinsipnya seperti satu like sama dengan satu vote. Sehingga untuk mengetahuinya maka perlu analisis secara mendalam terkait hal ini dengan menggunakan studi kasus akun @aliskamugemash.

\section{Metode Penelitian}

Dalam jurnal penelitian ini, peneliti memakai metode penelitian kualitatif deskriptif. Dengan metode penelitian yang ini, peneliti diharuskan untuk dapat menjelaskan, menggambarkan, dan menganalisis berbagai macam hal yang berkaitan dengan subjek penelitian dan digunakannya bahasa yang telah ditentukan (Creswell, 2014). Burhan Bungin mendeskripsikan penelitian kualitatif yang menjelaskan bagaimana metode pengumpulan data mengumpulkan data yang dibutuhkan sehingga hasil akhir penelitian dapat memberikan informasi yang valid (Bungin, 2017).

Teknik pengumpulan data yang peneliti gunakan ialah studi kepustakaan. Dimana studi kepustakaan sendiri berarti sebuah teknik pengumpulan data yang mana dalam prosesnya dilakukan dengan melakukan telaah terhadap buku, catatan, literatur, dan juga sumber tulisan lainnya yang berkaitan dengan hal hal yang masalahnya akan dipecahkan (Mirzakon \& Purwoko, 2017). Sedangkan, Teknik analisis data yang digunakan peneliti ialah menggunakan langkah-langkah sebagai berikut. Pertama, pengumpulan data dilakukan dengan cara data dikelompokan menjadi beberapa kelompok dengan menggunakan teknik studi kepustakaan. Kedua, Data-data yang telah dikelompokkan selanjutnya dianalisis dengan dibarengi dengan perbaikannya. Ketiga, 
setelah dilakukannya penganalisisan data, kemudian langkah terakhir yang dilakukan adalah menarik sebuah kesimpulan.

\section{Hasil dan Diskusi}

Berdasarkan hasil temuan tim peneliti terhadap akun @aliskamugemash ini, terbentuknya akun ini dilatarbelakangi oleh adanya kasus predator seksual bernama Leonardus Wahyu Dewala atau yang disngkat menjadi LWD. Akun ini digunakan sebagai media pergerakan digital untuk menyebarkan kesadaran dengan adanya seorang predator seksual sekaligus seorang penipu kepada seluruh masyarakat terkhusus perempuan di daerah Jawa atau bahkan di Indonesia. Pada awalnya, akun ini memposting berbagai macam kata-kata yang sering diucapkan oleh LWD dalam menjebak para korbannya. Selain itu, akun ini juga mengajak para korban LWD untuk angkat bicara mengenai apa yang dialami oleh para korban agar nantinya para masayarakat pun tahu tindakan seperti apa yang dilakukan oleh penipu ini. Seiring berjalannya waktu akun ini mulai mengunggah berbagai macam informasi yang menyangkut kasus LWD ini.

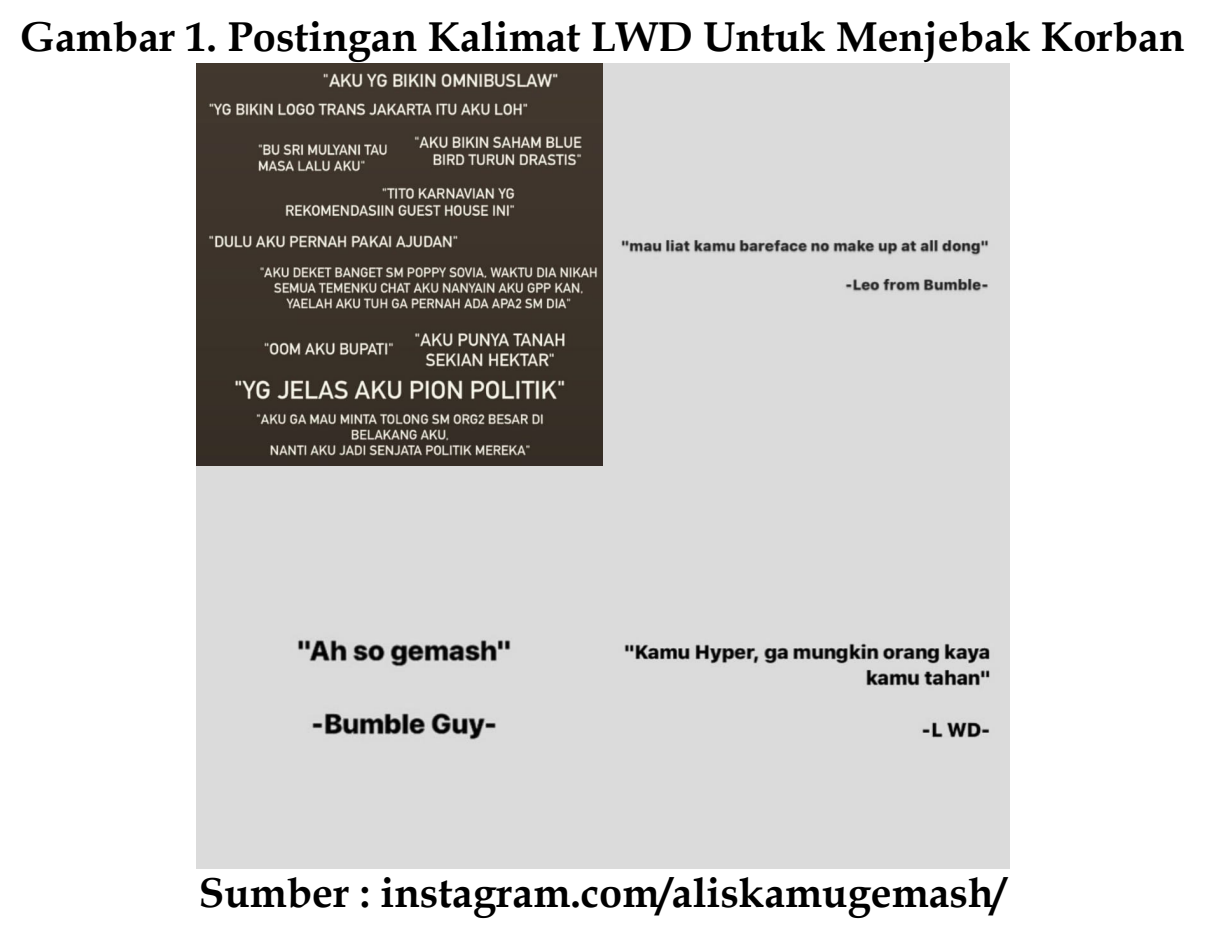

Gambar 2. Ajakan Untuk Angkat Bicara Terkait Kasus LWD 


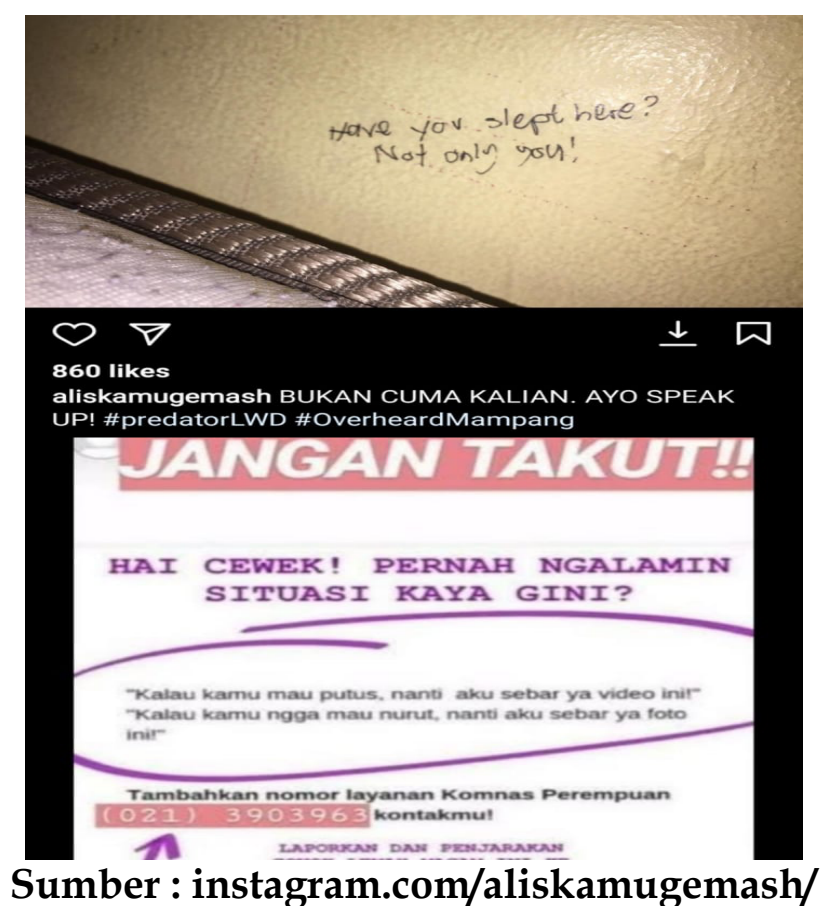

Walaupun hanya menggunakan platform Instagram sebagai perwujudan gerakan digital dalam menupas predator seksual ini, namun akun ini telah disebarluaskan oleh para pengguna jejaring media sosial lainnya, seperti Twitter yang kemudian jumlah pengikut @aliskamugemash pun meningkat pesat, terhitung pada tanggal 15 Juni 2021 ini pengikut akun tersebut telah mencapai 36.515 pengikut.

Membesarnya nama akun ini di muka publik selain dengan disebarkan oleh para pengguna jejaring media sosial, ternyata akun ini pun mendapat perhatian dan menerima dukungan pula oleh Poppy R. Dihardjo selaku aktivis dalam melawan kekerasan seksual yang kemudian dirinya membentuk akun @norecruitlist sebagai suatu komunitas yang berfokus kepada gerakan melawan kekerasan seksual. Dimana Poppy pun kerap kali diundang ke berbagai media penyiaran semisal stasiun radio 95,1 KIS Fm untuk menyebarkan awareness terkait kasus LWD ini. Berkat adanya akun ini dan semakin seringnya diperbincangkan oleh para pengguna media sosial, berbagai media pun mulai mengangkat kasus-kasus yang menyangkut LWD ini kepada publik, seperti mulai dipublikasikan pada pemberitaan online hingga stasiun televisi yakni Metro TV.

\section{Gambar 3. Kasus LWD Dipublikasikan Oleh Media}




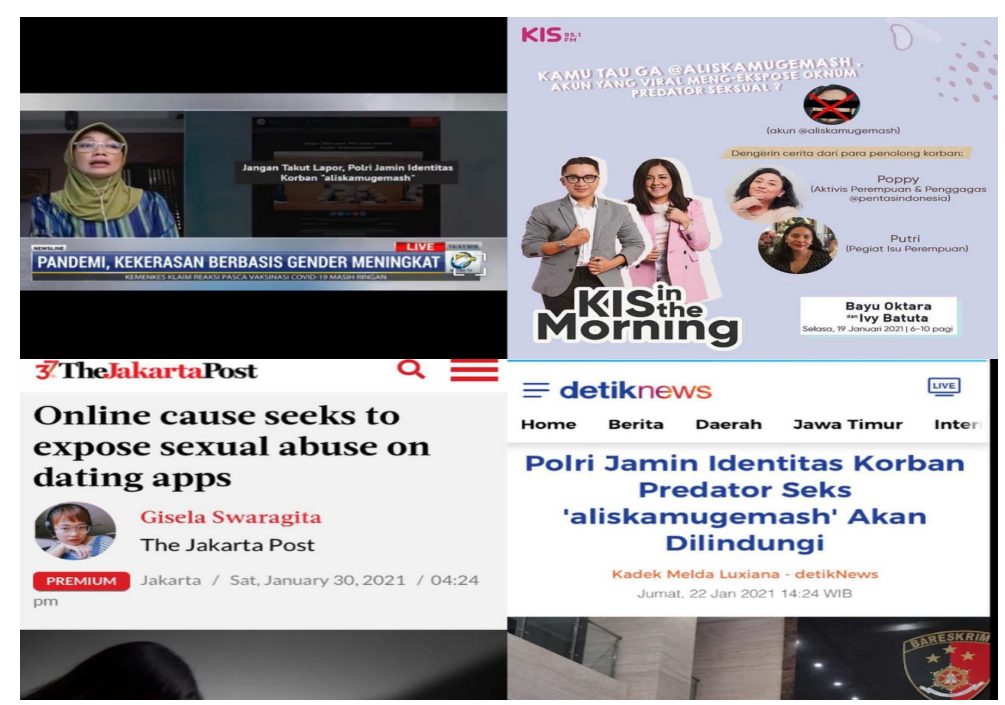

Sumber : instagram.com/aliskamugemash/

Kehadiran akun @aliskamugemash ini ialah sebagai suatu sarana bagi para korban agar berani untuk mengungkap tindakan tercela LWD kepada publik. Hal ini dibuktikan dengan berhasilnya akun ini untuk mengajak para korban untuk speak-up terkait perbuatan LWD, menurut informasi yang kami terima terhitung dari terbentuknya akun hingga hari ini admin akun @aliskamugemash telah menerima 70 bukti cerita dan 135 aduan yang diungkapkan oleh para korban melalui direct message atau DM.

Selain itu banyak ucapan dan dukungan yang diberikan oleh para pengikut akun yang dibentuk sejak tahun 2020 ini kepada pemilik akun @aliskamugemash karena mereka merasa terbantu, seperti menurut salah satu komentar yang diungkapkan oleh pengikutnya mengatakan jika dirinya menjadi lebih berhati-hati lagi dalam menggunakan aplikasi kencan online atau media sosial lainnya dan dirinya pun mendapati pengetahuan lebih terkait laman untuk melakukan pengaduan semisal dirinya menjadi korban pelecehan hingga kekerasan seksual. Salah satu pengikut yang menjadi korban dari kejahatan LWD pun mengatakan jika dirinya sangat bersyukur menemukan akun tersebut, karena dirinya dapat menyampaikan pengalamannya dengan aman (aliskamugemash, 2020).

Dari penjelasan tersebut, dapat dilihat bahwa pergerakan yang digencarkan oleh akun yang memiliki pengikut sebanyak 36 ribu ini merupakan bentuk connective action seperti yang diungkapkan oleh Segerberg (2013). Karena masing-masing individu yang bergerak dalam menyuarakan aspirasinya terhadap tindakan LWD ini tidak memerlukan suatu ikatan dengan para korban, melainkan tergerak dengan adanya rasa simpati yang dimunculkan setelah mengetahui perasaan para korban yang dapat dilihat melalui cerita-cerita yang diunggah pada akun tersebut. Akun media sosial Instagram @aliskamugemash dapat dikatakan sebagai ruang publik digital. Untuk menjawab asusmi tersebut kita perlu mengetahui apa yang dimaksud dengan ruang publik atau biasa disebut sebagai public sphere. Habermas mengatakan bahwa ruang publik sendiri pembentukanya didasari oleh perbincangan individu yang kemudian membentuk publik (Karatzogianni et al., 2016). Habermas menambahkan bahwa ruang publik sendiri merupakan suatu cara untuk menjelaskan opini publik beserta penyebarannya dalam hal tata kelola dan kebijakan publik (Karatzogianni et al., 2016). Berbeda dengan Habermas, Martin Gak menjelaskan bahwa ruang publik merupakan suatu ruang kontestasi dan 
promosi daripada individu serta kepedulian kolektif beserta alasan untuk hal tersebut (Karatzogianni et al., 2016).

Jostein Gripsrud \& Hallvard Moe memaparkan penjelasan yang lebih ringkas lagi yangmana mereka menjelaskan ruang publik sebagai tempat dimana masyarakat mengkomunikasikan terkait peraturan dalam lingkup masyarakatnya (Gripsrud \& Moe, 2010). Sehingga disini, ruang publik berarti sebuah ruangan tempat berkomunikasi melalui perbincangan yang ada antar individu hingga kemudian membentuk publik. Media massa memiliki peranan sebagai infrastruktur penunjang bagi ruang publik modern yang mana media massa seperti media cetak hingga media eletronik semisal televisi hingga internet pada masa kini yang dengan mudah mendistribusikan informasi, berbagai bentuk argumentasi dan pemikiran tentang fakta, permasalahan juga solusinya (Gripsrud \& Moe, 2010). Sebagai infrastruktur ruang publik modern, internet telah mengambil alih posisi penting bagi politik, ekonomi, juga kehidupan sosial dimana Slavko Splichal mengatakan bahwa berbeda dengan publikasi termediasi tradisional, media penyiaran dan surat kabar yang tak interaktif, internet memberikan penawaran baru bagi partisipasi komunikasi (Gripsrud \& Moe, 2010).

Dari penjelasan tersebut didapati simpulan bahwa media sosial Instagram @aliskamugemash menjadi wadah sebagai gerakan penuntasan kasus LWD di mana secara interaktif publik berinteraksi dan juga melaporkan kejahatan yang dilakukan oleh LWD sehingga media sosial Instagram @aliskamugemash ini menjadi sebuah ruang publik digital karena pada laman media sosial tersebut dijadikan sebagai ruang untuk berbincang dan beropini antar individu hingga kemudian membentuk publik yakni followers laman media sosial Instagram @aliskamugemash dimana pada paradigma ruang publik yang lama, orang-orang menggunakan cafe, saloon, atau coffeshop sebagai arena ruang publik namun kini sebagai dampak kemajuan teknologi, ruang publik merambah ke dunia virtual yakni internet (Karatzogianni et al., 2016). Pada laman Instagram @aliskamugemash didapati interaksi sebagai respon dari laporan yang diajukan para korban.

Gambar 4. Interaksi Respon Warganet dari Laporan Para Korban 


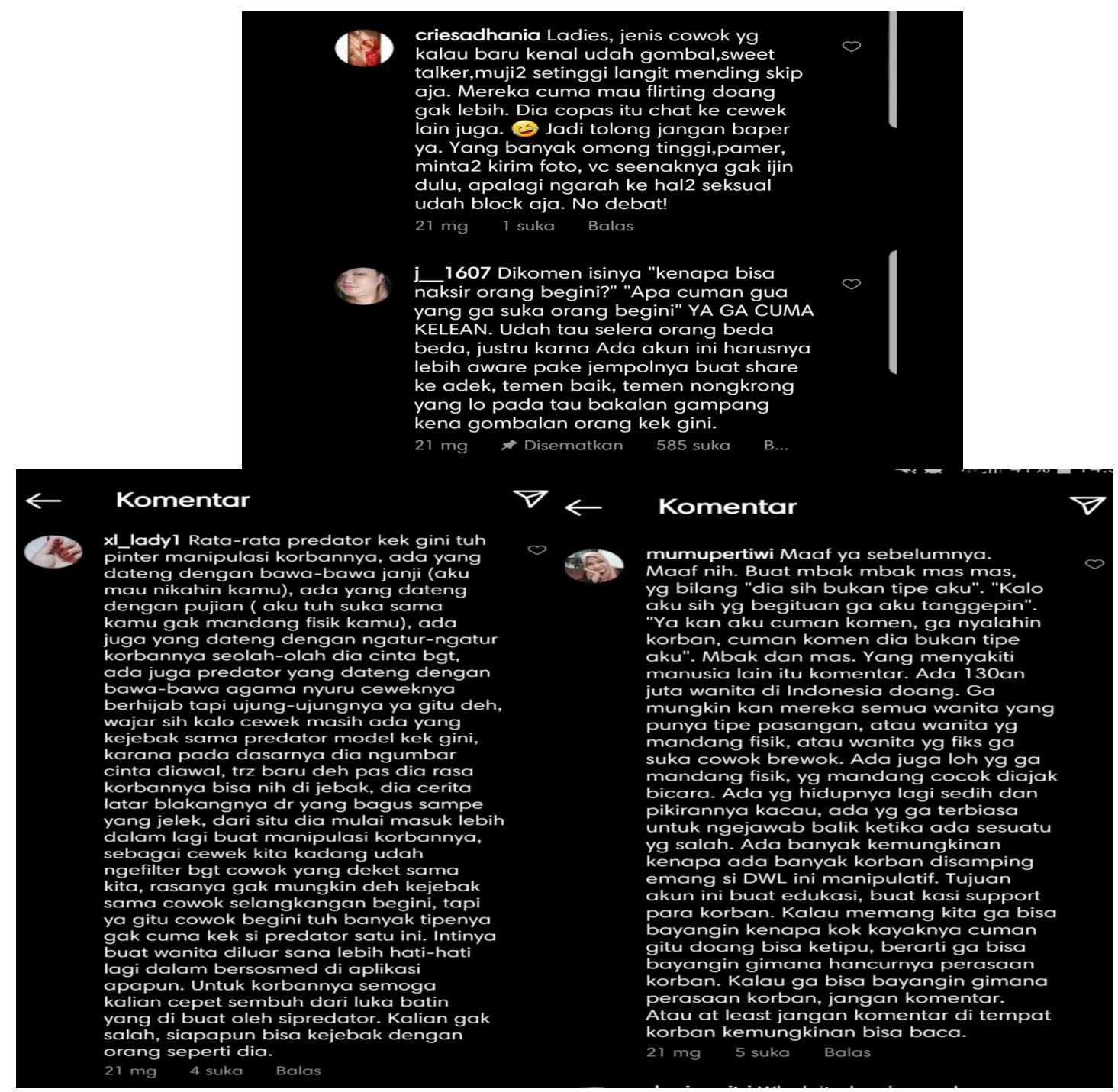

Sumber : instagram.com/aliskamugemas

Laman media sosial Instagram @aliskamugemash kemudian menjadi sebuah ruang interaksi publik yang merespon kejahatan LWD dalam laman media sosial @aliskamugemash dimana laman media sosial tersebut menjadi suatu wadah pertukaran informasi, opini publik terkait kejahatan LWD yang diungkapkan ke publik. Sebagai ruang publik yang diisi oleh publik dalam hal ini publik yang melawam tindakan LWD, laman media sosial Instagram @aliskamugemash menjadi sebuah wadah gerakan perlawanan terhadap LWD melalui media sosial dimana Bonilla dan Rossa mengatakan bahwa media sosial ini merupakan medium atas perlawanan yang membuka ruang kontestasi serta dapat memberikan narasi dengan versi lain dari yang diutarakan pada media mainstream (Melgaço \& Monaghan, 2018). Pemberian komentar serta dukungan pada kolom komentar atau melalui direct message yang ditunjukkan oleh para pengikut dari akun yang memiliki jumlah followers sebanyak 36 ribu terhadap kasus penipuan dan predator seksual yang menyangkut LWD ini pun mencerminkan bahwa mereka secara tidak langsung telah turut berpartisipasi dalam sebuah gerakan yang dilakukan secara daring, sehingga hal ini dapat dinilai sebagai bentuk perwujudan dari digital citizenship. Di mana menurut Moosberger (2008) digital citizenship merupakan suatu masyarakat 
yang menggunakan internet sebagai kebiasaan dalam kesehariannya dan mempunyai kemampuan untuk berpartisipasi dalam lingkup masyarakat secara daring.

Media sosial sebagai ruang publik digital di dalamnya terjadi kolektivitas dan pertukaran informasi yang membantu artikulasi atas bauran atau keumuman kepentingan politis yang cukup inklusif untuk menyatukan keberagaman demografis yang heterogen (Karatzogianni et al., 2016). Beck dan Beck-Gernsheim mengatakan bahwa media sosial ini mencerminkan masyarakat secara individual sehingga berujung pada framming pengguna yakni individu (Trottier \& Fuchs, 2015). Sehingga disini, laman media sosial @aliskamugemash sebagai ruang publik menjadi ruang pertukaran informasi antar korban LWD namun dari hasil penelusuran kami, laman Instagram tersebut mencerminkan masyarakat secara individual yakni sosok korban dari LWD dan berujung pada framing yang ditujukan pada kasus atau tindakan LWD terhadap korban korbannya.

Dalam suatu gerakan sosial, untuk memobilisasi orang dibutukan komponen subyektif yakni elemen atas persepsi dan kesadaran yang mana telah terkonsepkan sebagai proses sosio-psikologis yang disebut sebagai framing (Johnston \& Noakes, 2005). Fungsi daripada framing ini ialah untuk mendapatkan perhatian yang terfokus pada apa yang relevan, penting, dan menjauhi hal-hal asing dalam suatu sudut pandang (Johnston \& Noakes, 2005). Disini framing yang difokuskan ialah bagaimana kejahatan LWD terhadap para korbannya, akun @aliskamugemash ini membuka percapakan melalui Direct Message untuk para korban menceritakan pengalaman buruknya bersama LWD ini kemudian hasil dari percapakan tersebut akan di screenshot dan post di akun @aliskamugemash, kebanyakan para korban mendapatkan modus ajakan untuk mampir ke kediaman LWD ini. LWD pintar untuk menarik perhatian para korban dan membuat korban jatuh hati dan rela melakukan apapun untuk LWD. Kebanyakan korban mulai menyadari bahwa LWD melakukan ini bukan hanya pada dirinya melainkan pada banyak wanita lain.

\section{Gambar 5. Bukti Kejahatan LWD Terhadap Korbannya}

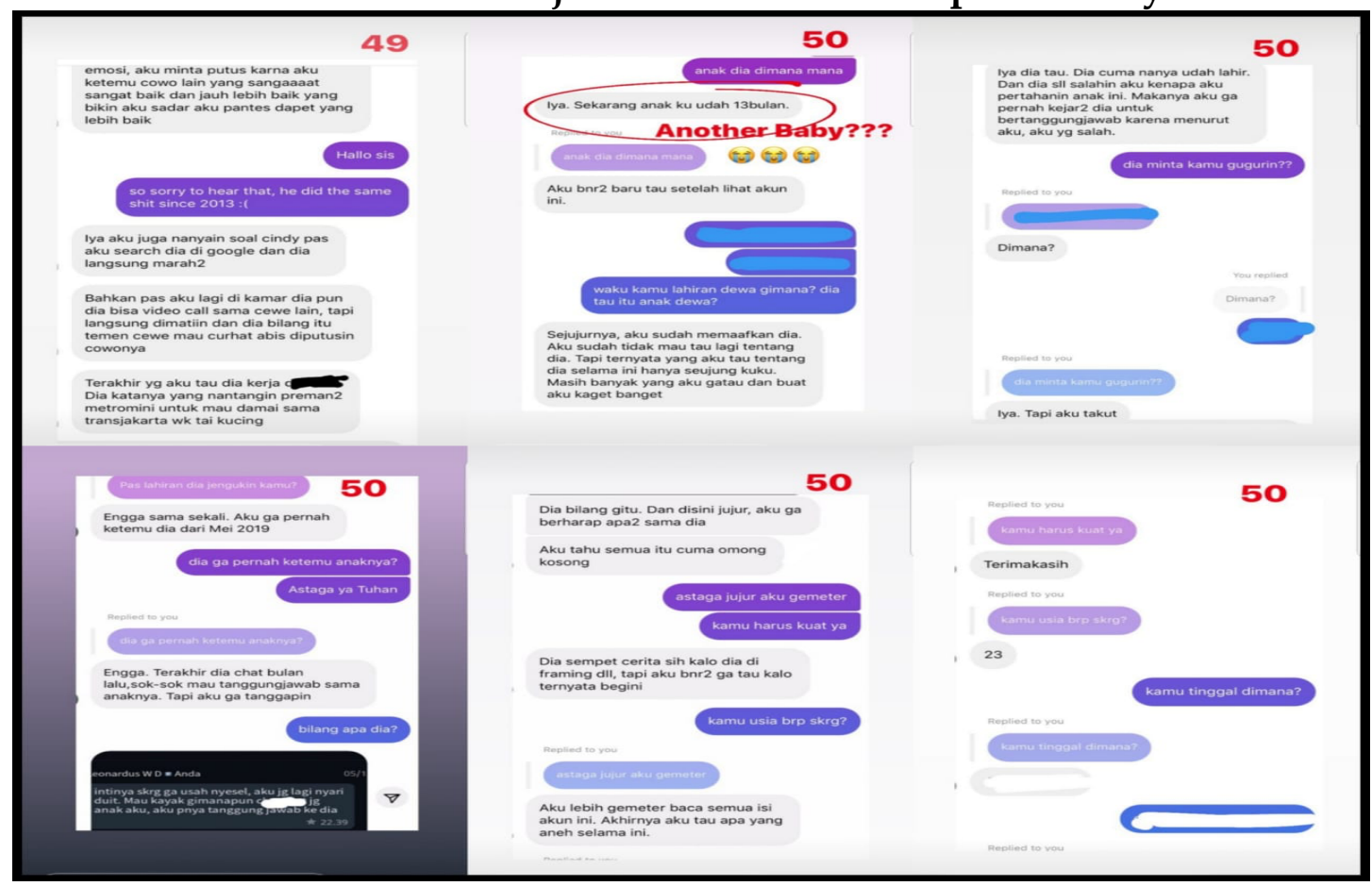

Sumber : instagram.com/aliskamugemash/ 
Namun, mengutip isi dari buku Frames of Protest Social Movements and The Framing Perspective, nyatanya framing ini menjadi suatu kunci bagi gerakan sosial sebagai instrumen guna memotivasi partisipan dimana gerakan harus memproduksi nilai-nilai yang dapat menjelaskan permasalahan, menyoroti isu yang ada, dan menghiraukan yang tidak berkaitan dimana ini dapat dilakukan melalui framing (Johnston \& Noakes, 2005). Sehingga pada intinya framing yang ada dapat mengidentifikasi permasalahan yang dibawa oleh suatu gerakan sosial di mana untuk laman media sosial Instagram @aliskamugemash sendiri, framing yang dibawa ialah sosok LWD sebagai predator seksual.

Dalam suatu framing sebuah gerakan sendiri biasanya memuat komponen ketidakadilan yakni sesuatu yang salah dan harus diubah (Johnston \& Noakes, 2005). Walaupun akun ini sudah berjalan dengan semestinya, maksudnya ialah sebagai media pergerakan digital untuk menyebarkan informasi kepada publik dan sebagai wadah dalam penyampaian aduan dari kasus LWD. Namun tujuan utamanya pun masih belum tercapai, yang mana tujuan utamanya yakni tertangkapnya LWD selaku sosok predator seksual dan penipu. Hal ini disebabkan masih takutnya para korban jika identitas dirinya akan diungkap, padahal Brigjen Pol Rudi Hartono selaku Karo Penmas Divisi Humas Mabes Polri (dalam Briantika, 2021) mengatakan jika pihak kepolisian akan menjamin jika identitas dari para korban tidak akan diketahui oleh pihak luar atau bahkan dipublikasikan.

Dampak dari adanya akun @aliskamugemash ini sebagai gerakan sosial adalah para korban akhirnya mengetahui siapa sosok LWD ini dan membuat mereka sadar kalau selama ini mereka sudah menjadi korban kejahatan LWD. Bahkan dengan adanya akun ini akhirnya para korban berani untuk bersuara dan menceritakan kejadian yang mereka alami bersama LWD. Selain itu akun @aliskamugemash ini juga menyuarakan hak-hak perempuan untuk mendapatkan payung hukum melalui penerapan undang-undang pornografi. Jelas sekali bahwa akun ini bergerak untuk para perempuan untuk mendapatkan haknya dan mencegah adanya korban selanjutnya

\section{Kesimpulan}

Berdasarkan pembahasan yang telah penulis uraikan di atas menghasilkan berbagai perilaku digital masyarakat dalam menyuarakan ketidakadilan terhadap korban pelecehan seksual LWD. Dibuktikan dengan pergerakan sosial dari pemanfaatan teknologi digital yang dilakukan melalui penggunaan media baru yakni Instagram dengan username @aliskamugemash, telah berhasil membawa isu ini menjadi viral, dampak positifnya ditunjukan dengan perilaku digital masyarakat yaitu para pengguna media sosial laki-laki dan khususnya perempuan, mengetahui persoalan ini sehingga lebih berhati-hati dalam melakukan interaksi dengan pengguna asing di aplikasi kencan online serupa Tantan dan Badoo dengan modus yang menyerupai LWD. Pada laman sosialnya terlihat pergerakan yang digencarkan oleh akun @aliskamugemash dengan pengikut sebanyak 36 ribu hal ini merupakan bentuk connective action, sejalan dengan apa yang diungkapkan oleh Segerberg (2013). Karena masing-masing individu yang bergerak dalam menyuarakan aspirasinya walau bukan bagian dari korban namun bergerak dengan rasa simpati, sebagai sesama perempuan, juga laki-laki yang menjaga dan melindungi hak perempuan. Dan secara tidak langsung para masyarakat yang telah menyampaikan aspirasi serta dukungannya melalui akun @aliskamugemash ini 
merupakan suatu perwujudan dari digital citizenship seperti yang telah disampkain oleh Mossberger (2008).

Sebuah gerakan sosial, membutuhkan upaya dalam memobilisasi individu dibutukan komponen subyektif yakni elemen atas persepsi dan kesadaran yang mana telah terkonsepkan sebagai proses sosio-psikologis yang di sebut sebagai framing (Johnston \& Noakes, 2005). Kegunaan framing ini ialah untuk mendapatkan perhatian yang terfokus pada sosialisasi kejahatan seksual yang dilakukan LWD. Meskipun tujuan memenjarakan LWD sebagai tujuan utama belum tercapai dengan upaya @aliskamugemash, ini juga menyuarakan hak-hak perempuan untuk mendapatkan payung hukum melalui penerapan undang-undang pornografi. Setidaknya tujuan mereka untuk mendapat simpatik publik demi keamanan dan kehati-hatian perempuan telah berhasil diupayakan, melalui pergerakan yang mengkampanyekan kejahatan LWD dalam bentuk tulisan berisi cerita para korban dan motif kejahatan LWD yang disosialisasikan dengan perilaku digital masyarakat yang bersimpatik dan waspada.

\section{Referensi}

Aliskamugemash. (2020). Mas Tersayang. Retrieved May 31, 2021 from https://www.Instagram.com/aliskamugemash.

Anggraeni, L. (2020). Mengenal Aplikasi Tinder yang Sedang Ramai Dibicarakan. Retrieved May 31, 2021 from https://www.medcom.id/teknologi/newsteknologi/GNl431VN-mengenal-aplikasi-tinder-yang-sedang-ramaidibicarakan?_cf_chl_jschl_tk_=ae9063112aa855ebfab1fc1dc208e88dbab145991618906625-0-ASM-v_iW7boiriI_y-fEmv0knbzfUvZTtl08__EkI6rQ62OxUTcjNqJJLPwCvK_2bgoxe

Ariana, N. T. (2021). Fakta Lengkap Leonardus Wahyu Dewala Viral Diduga Predator dengan Pickup Line Alis Kamu Gemas . Retrieved May 31, 2021 from https://kuyou.id/homepage/read/18124/fakta-lengkap-leonardus-wahyu-dewala-viraldiduga-predator-dengan-pickup-line-alis-kamu-gemas.

Briantika, A. (2021). Jangan Takut Lapor, Polri Jamin Identitas Korban “aliskamugemash.". Retrieved May 31, 2021 from https://tirto.id/jangan-takut-laporpolri-jamin-identitas-korban-aliskamugemash-f9v9.

Bungin, B. (2017). Metodologi Penelitian Kualitatif. Jakarta : Raja Grafindo.

Creswell, J. W. (2014). Research Design: Qualitative, Quantitative and Mixed Methods. Approaches (Fourth). New York : SAGE Publications.

Gripsrud, J., \& Moe, H. (2010). The Digital Public Sphere Challenges for Media Policy. Gothenburg : Nordicom.

Johnston, H., \& Noakes, J. A. (2005). Frames of Protest Social Movements and The Framing Perspective. New York : Rowman \& Littlefield Publishers.

Karatzogianni, A., Nguyen, D., \& Serafinelli, E. (2016). The Digital Transformation of the Public Sphere. London : Palgrave Macmillan.

Koc-Michalska, K., Lilleker, D. G., \& Vedel, T. (2016). Civic political engagement and social change in the new digital age. New Media and Society, 18(9), 1807-1816. 
Melgaço, L., \& Monaghan, J. (2018). Protest in the Information Age Social Movements, Digital Practices and Surveillance. London : Routledge.

Mirzakon, T. A., \& Purwoko, B. (2017). Studi Kepustakaan Mengenai Landasan Teori Dan Praktik Konseling Expressive Writing. Jurnal BK Unesa, 8(1).

Mossberger, K., Tolbert, C. J., \& Mcneal, R. S. (2008). Digital Citizenship The Internet, Society, and Participation. London : The MIT Press.

Nurfajriani, R. (2020). Mutilasi di Kalibata City Bukan yang Pertama, Ini 3 Kasus Pembunuhan karena Tinder. Retrieved May 27, 2021 from https://www.pikiranrakyat.com/internasional/pr-01752947/mutilasi-di-kalibata-city-bukan-yang-pertama-ini3-kasus-pembunuhan-karena-tinder?page $=3$.

Segerberg, A. (2013). The Logic of Connective Action: Digital Media and the Personalization of Contentious Politics (Cambridge Studies in Contentious Politics). Cambridge : Cambridge University Press.

Slamet, A. (2010). Proses Sosial dan Interaksi Sosial. Retrieved May 27, 2021 from https://repository.unikom.ac.id/34308/1/Proses sosial dan Interaksi sosial.pdf.

Trottier, D., \& Fuchs, C. (2015). Social Media, Politics and the State. New York: Routledge. 